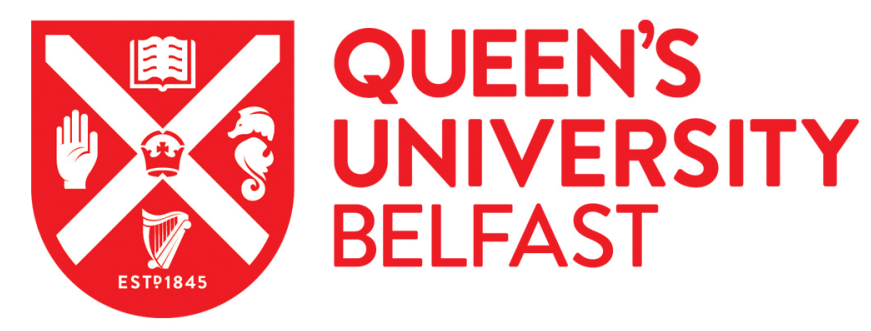

\title{
Empathy to action: Child and adolescent out-group attitudes and prosocial behaviors in a setting of intergroup conflict
}

Taylor, L., O'Driscoll, D., Dautel, J. B., \& McKeown, S. (2020). Empathy to action: Child and adolescent outgroup attitudes and prosocial behaviors in a setting of intergroup conflict. SOCIAL DEVELOPMENT, 29(2), 461477. https://doi.org//10.1111/sode.12421, https://doi.org/10.1111/sode.12421

\section{Published in: \\ SOCIAL DEVELOPMENT}

\section{Document Version:}

Peer reviewed version

Queen's University Belfast - Research Portal:

Link to publication record in Queen's University Belfast Research Portal

Publisher rights

Copyright 2019 Wiley. This work is made available online in accordance with the publisher's policies. Please refer to any applicable terms of use of the publisher.

\section{General rights}

Copyright for the publications made accessible via the Queen's University Belfast Research Portal is retained by the author(s) and / or other copyright owners and it is a condition of accessing these publications that users recognise and abide by the legal requirements associated with these rights.

Take down policy

The Research Portal is Queen's institutional repository that provides access to Queen's research output. Every effort has been made to ensure that content in the Research Portal does not infringe any person's rights, or applicable UK laws. If you discover content in the Research Portal that you believe breaches copyright or violates any law, please contact openaccess@qub.ac.uk. 
Running header: EMPATHY TO ACTION

\title{
Empathy to action: Child and adolescent outgroup attitudes and prosocial behaviors in a setting of intergroup conflict
}

Laura K. Taylor ${ }^{1,2}$, Dean O’Driscoll ${ }^{2}$, Jocelyn B. Dautel ${ }^{2}$ \& Shelley McKeown ${ }^{3}$

\author{
${ }^{1}$ University College Dublin \\ ${ }^{2}$ Queen's University Belfast \\ ${ }^{3}$ University of Bristol
}

\section{Acknowledgements:}

Study 1 was supported financially by the School of Psychology Research Incentivisation Scheme and Summer Student Scheme as well as through the countless hours of data collection by our undergraduate and Master's student research team in the Helping Kids! lab (http://helpingkidsqubblog.wordpress.com). Dean O’Driscoll was supported by a Department of Employment and Learning (DEL) studentship [\#00417416]. Study 2 was supported by the Richard Benjamin Trust and the British Academy (BA) / Leverhulme [SG 150807]. Finally, we would like to extend our deep appreciation to the numerous school administrators, teachers, parents, and pupils for participating in these studies. The authors have no known conflict of interests with this work. The data that support the findings of this study are available on request from the corresponding author. 
Correspondence concerning this article should be addressed to Laura K. Taylor, School of Psychology, University College Dublin, Belfield, Dublin, IRELAND. E-mail:

laura.taylor@ucd.ie 
The paper explored how to promote constructive intergroup relations among children and young people in a context of protracted conflict. Across two studies, the Empathy-AttitudesAction model was examined in middle childhood and adolescence. More specifically, we tested the relations among dispositional empathy, outgroup attitudes, and prosocial behaviors for youth born after the peace agreement in Northern Ireland. In one correlational (Study 1: $\mathrm{N}$ $=132$; 6 - to 11 -years-old: $M=8.42$ years, $S D=1.23$ ) and one longitudinal design (Study 2: $\mathrm{N}=466$; 14- to 15-years-old), bootstrapped mediation analyses revealed that empathy was associated with more positive attitudes toward the conflict-related outgroup, which in turn, was related to higher outgroup prosocial behaviors, both self-report and concrete actions. Given that outgroup prosocial acts in a setting of intergroup conflict may serve as the antecedents for peacebuilding among children and adolescents, this study has intervention implications.

Keywords: empathy; prosocial behavior; intergroup processes; conflict resolution; children; adolescents 


\section{Empathy to action: Child and adolescent outgroup attitudes and prosocial behaviors in a setting of intergroup conflict}

In conflict settings, research often focuses on understanding how cycles of violence are perpetuated through negative attitudes and behaviors, such as prejudice (Turner, Tam, Hewstone, Kenworthy, \& Cairns, 2013) and aggression (Merrilees et al., 2013; Taylor, Merrilees, Goeke-Morey, Shirlow, \& Cummings, 2016). Less is known about the development of youth outcomes that may promote more constructive intergroup relations (Taylor, Merrilees, Goeke-Morey, Shirlow, \& Cummings, 2014). For example, prosocial behaviors, or voluntary actions aimed to benefit or improve the welfare of others (Dovidio, Piliavin, Schroeder, \& Penner, 2017), such as helping, comforting, and sharing (Eisenberg, Eggum, \& Di Giunta, 2010), may be the antecedents of later peacebuilding when targeted at the traditional rival group (McEvoy-Levy, 2006; Taylor \& McKeown, 2017).

Identifying the mechanisms underlying positive outgroup attitudes and prosocial behaviors among children may have long-lasting benefits in conflict-affected societies (BarTal, Diamond, \& Nasie, 2017). Indeed, intergroup attitudes can motivate behaviors that are associated with children's peacebuilding (O’Driscoll, Taylor, \& Dautel, 2018), laying a foundation for intergroup collaboration (Kelman, 2008). Evidence also shows that empathy can promote positive attitudes and, in turn, encourage positive action amongst adults (Batson, Chang, Orr, \& Rowland, 2002; Taylor \& Hanna, 2018). The potential processes linking empathy, attitudes, and action, however, has yet to be examined with children and adolescents in a setting of intergroup conflict. The current paper extends previous work by exploring the role of empathy in promoting positive outgroup attitudes and prosocial behaviors among children and adolescents in post-accord Northern Ireland. The findings may have real world implications, as intergroup helping may prompt both groups to work together and establish more peaceful intergroup relations (Kelman, 2008). 


\section{Post-accord Northern Ireland}

Northern Ireland is a society emerging from decades of intergroup conflict, and despite the signing of the Belfast/Good Friday Peace Agreement in 1998, relations continue to be strained. The region remains split along ethno-political lines, i.e., between Protestants and Catholics, and these intergroup divisions shape the social interactions of those growing up as part of a post-accord generation (Cummings, Goeke-Morey, Merrilees, Taylor, \& Shirlow, 2014). That is, ethno-political identity remains a key social dimension and maintains perceptions of "us" and "them". Approximately 94\% of Protestant and Catholic children attend separate primary and post-primary schools (Northern Ireland Department of Education, 2017). They tend to live in segregated neighborhoods and spend time with peers from their own community. Evidence also shows that many children have firsthand experience dealing with prejudice and annual escalations of political violence (Leonard, 2010). Thus, the legacy of conflict, which leaves physical and psychological partitions between the two communities, even affects children born after the peace agreement, or the 'post-accord generation.'

Young people, however, also may play an essential role in peacebuilding (McKeown \& Taylor, 2017; Taylor \& McKeown, 2017). Those born after the height of intergroup violence may be more open to dismantling traditional conflict dynamics (Taylor et al., 2014). Thus, the post-accord generation in Northern Ireland provides a good case to study how to promote constructive forms of engagement, such as outgroup prosocial behaviors, which may have long-term implications for intergroup cooperation and peacebuilding (Kelman, 2008).

\section{Empathy-Attitudes-Action Model}

Empathy often motivates prosocial behaviors toward others (Batson, 1991; Batson \& Moran, 1999). To this end, the Empathy-Attitudes-Action model (EAA) was developed to describe how empathy can foster helping within intergroup contexts (Batson et al., 2002). 
Distinct from related constructs such as personal distress, perspective taking, and sympathy, EAA defines empathy as "an other-orientated emotion caused by and congruent with the perceived welfare of someone else" (Batson, 2010, p. 22) which can promote positive attitudes and in turn, encourage positive action. This increased valuing of an individual outgroup member may generalize to the collective outgroup and promote more overall positive outgroup attitudes (Batson et al., 1997). EAA argues that these positive outgroup attitudes then form the basis for engaging in constructive action across group lines (Batson et al., 2002).

Evidence for empathy-based attitude change has been demonstrated with undergraduate samples across a range of stigmatized groups, including people with AIDS, those experiencing homelessness, and even convicted murderers (Batson et al., 1997). Importantly, the effect of empathy can be relatively long-lasting, even when the recipient of the empathy is an atypical group member or is perceived to be responsible for his/her fate (Batson et al., 1997). For example, among adults, feeling empathy for someone dependent on heroin produced more favorable evaluations of people struggling with drug addiction in general, and in turn, led to more resources being allocated to help that group (Batson et al., 2002). Complementing this research with emerging adults, there also is evidence that empathy is an important predictor of children's prosocial behavior (Sierksma, Thijs, \& Verkuyten, 2015), and yet, to date, the EAA model has not been applied in developmental research.

\section{Empathy and Action}

Evidence shows that feeling empathy for others is an essential component of everyday interactions in middle childhood (Findlay, Girardi, \& Coplan, 2006). Empathy has been linked to increased prosocial behavior among six-year-old children (Eisenberg \& Miller, 1987; Malti, Gummerum, Keller, \& Buchmann, 2009), and is likely to encourage helping in 
intergroup contexts among 8- to 13-year-olds (Sierksma et al., 2015). Previous research has shown that differences in empathy may have an impact on prosocial behavior toward different social groups in middle childhood and early adolescence (Sierksma, Thijs, \& Verkuyten, 2014). For example, higher levels of dispositional empathy, or the ability to imagine and understand others' feelings and experiences, among 5- to 10-year-olds was related to greater prosociality toward an outgroup member, even when intergroup dynamics were competitive (Abrams, Van de Vyver, Pelletier, \& Cameron, 2015). In addition, empathy-induction in children has also been shown to reduce differences in helping intentions between imagined ingroup and outgroup peers (Sierksma et al., 2015; Taylor \& Glen, 2019). Therefore, higher empathy may promote positive action between groups; however, the underlying mechanism remains unclear and this link has not been explored with natural groups in settings emerging from violent intergroup conflict.

\section{Empathy to Attitudes}

Previous research suggests that empathy may contribute to the socialization of children's attitudes toward other social groups (Aboud \& Levy, 2000), given that empathy increases children's valuing of others' welfare as early as four to five years old (Batson \& Ahmad, 2009; Miller, Eisenberg, Fabes, \& Shell, 1996). That is, empathy may improve children's social understanding and encourage them to be more considerate of the feelings and needs of other people (Eisenberg, 1990). Interventions aimed at increasing outgroup empathy among children also have seen improved attitudes in both conflict and non-conflict settings (Beelmann \& Heinemann, 2014). For example, in Sri Lanka, Sinhalese and Tamil emerging adults who took part in a 4-day peace workshop reported feeling more empathy and more positive attitudes toward outgroup members both concurrently and one year later (Malhotra \& Liyanage, 2005). More generally, 5- to 12-year-old children with higher dispositional empathy showed a greater liking of ethnic outgroup members (Nesdale, 
Griffiths, Durkin, \& Maass, 2005). Stephan and Finlay (1999) suggested that empathy may be effective in reducing intergroup conflict and the accompanying social prejudice. Complementing the mounting body of work that aims to reduce children's negative intergroup evaluations and prejudice (Rutland, Abrams, \& Levy, 2007), empathy also may foster positive attitudes and behaviors that may improve intergroup relations (Aboud et al., 2012), particularly in divided societies (Turner et al., 2013).

\section{Attitudes to Action}

Attitudes can lead to concrete action (for review, see Ajzen \& Fishbein, 2005). Holding negative perceptions of another social group may encourage intergroup avoidance and even promote destructive forms of engagement, such as outgroup-directed aggression across middle childhood and through adolescence (Merrilees et al., 2013). Similarly, positive outgroup attitudes may facilitate approach responses, including helping behaviors across group lines in teen samples (Taylor et al., 2014). Toward this end, attitudes also may influence children's intergroup interactions, including outgroup prosocial behaviors. For example, 7- to 9-year-old children with favorable perceptions of immigrants were more willing to help immigrant children following a natural disaster (Vezzali, Cadamuro, Versari, Giovannini, \& Trifiletti, 2015). Extending this pattern of findings, among 5- to 9-year-old children in Northern Ireland, more positive attitudes toward the former rival related to sharing more resources with outgroup members (O’Driscoll et al., 2018). Similarly, adolescents' attitudes toward conflict-related groups were predictive of their outgroup prosocial behaviors one year later (Taylor et al., 2014). These studies suggest that more positive outgroup attitudes among children may relate to more outgroup prosocial behaviors.

\section{Current Paper}

Advancing theory, this paper applies a developmental intergroup framework (Abrams \& Killen, 2014) to understand EAA. The framework explicitly integrates social and 
developmental psychology, noting the critical interdependence of the individual and his/her social context. For example, intergroup processes among adults may look different in childhood. Social-cognitive abilities such as decision making, social perspective taking, and morality are developing in tandem to children's understanding of social categories and group identity (Rutland, Killen \& Abrams, 2010). At the same time, developmental theories often neglect the influence of group identities and dynamics (Bennett \& Sani, 2004). For example, sociocognitive theories about the development of negative outgroup attitudes (e.g. Aboud, 1988) largely do not discuss how the social environment may influence these processes. Thus, by examining EAA through the developmental intergroup framework, this paper may shed new light on the role of empathy in relation to dynamic intergroup processes, in a context of historic intergroup threat and group-favoring social norms.

Recognizing the importance of social context, the studies are conducted in postaccord Northern Ireland. Given that children and adolescents in this setting are often viewed as victims or as troublemakers continuing the cycle of violence (Muldoon, 2013), this approach to understanding intergroup relations is important because it focuses on their peacebuilding potential (McEvoy-Levy, 2006). Consistent with earlier research (5-10 years old: Abrams et al., 2015; 5-12 years old: Nesdale et al., 2005; 8-13 years old: Sierksma et al., 2015), we hypothesize that dispositional empathy will be related to more outgroup prosocial behaviors. We expect outgroup attitudes to mediate this relation among children and adolescents in a post-accord generation.

\section{Study 1}

Extending previous research, Study 1 focused on the role of dispositional empathy in promoting positive outgroup attitudes and prosocial behaviors during middle childhood.

\section{Method}

\section{Participants}


Children were recruited from five primary schools in Belfast (three state controlled de facto Protestant schools and two Catholic-maintained schools) in fall 2016 through spring 2017. One hundred and sixty-three children received parental consent to take part in the study ( $29 \%$ opt-in return rate, equal across both community backgrounds), however, thirteen were absent from school at the time of data collection. Five children were tested, but were omitted from further analyses, as they were not born in Northern Ireland, including the two participants who indicated they were from an ethnic/racial minority background. Thirteen pairs of siblings also were tested; however, in order to avoid nested family influence, data from one sibling were removed at random. The final sample therefore consisted of 132 children, ages 6- to 11 -years-old $(M=8.42$ years, $S D=1.23)$. The children were roughly balanced by gender ( $56 \%$ female, $n=74 ; 44 \%$ male, $n=58$ ), with 91 from the Protestant community (69\%) and 41 from the Catholic community (31\%). This sample size has a statistical power of .80 to detect a medium effect size in a multiple regression framework, given the number of predictors (Cohen, 1992).

Primary schools that took part in the study were separated by religion, with the majority $(>70 \%)$ of students being either Protestant or Catholic within each school (Northern Ireland Department of Education, 2016). The sample intentionally included interface schools (i.e., controlled and maintained school side-by-side, separated by only a 'peace wall' or some other physical boundary, see McKeown \& Taylor, 2017). This approach facilitates potential variability in the contact with or awareness about the outgroup. Interface schools, however, tend to have higher percentages of students eligible to receive free school meals (FSM); therefore, non-interface schools were also selected from this range of FSM. Within each participating school, more than $70 \%$ of students were eligible to receive FSM.

\section{Procedure}


School principals gave permission for data collection to take place within their primary school. A packet containing a parental consent form and information letter was then sent home with all children in school years (grades) 3 to 7 . Only children with opt-in parental consent participated in the study, and children provided written assent before taking part. Child data were collected in two testing sessions over the course of a week.

First, children were taken out of class in small groups to complete a response booklet on dispositional empathy which took around 10 minutes to complete. Trained experimenters provided instructions on how to complete the booklet, and children were taught how to use the simplified Likert-type scales before moving on to the primary questions. Children completed the booklet at the same pace, as one experimenter read each item aloud before children selected their response. Another experimenter was also available to answer any questions.

Second, children were tested individually by the experimenters in a quiet area of their classroom. This session lasted around 15 minutes, and children completed a set of training items before the measures that assessed their outgroup attitudes and outgroup prosocial behavior. After children had completed both sessions, they received a certificate and a small prize. Primary schools were each compensated with a $£ 75(\sim \$ 100)$ Amazon gift voucher.

\section{Measures}

Dispositional empathy. Empathy was measured using a version of the empathic concern subscale of the Interpersonal Reactivity Index (IRI) (Davis, 1983) that had been adapted for 5- to 8-year-old children (Catherine \& Schonert-Reichl, 2011). Previous research had successfully used similar child-friendly measures of empathy (Nesdale et al., 2005). The current scale comprised of 6-items including, 'I often feel sorry for other children who are sad or in trouble' and 'It makes me sad to see a child who can't find anyone to play with.' Rather than a binary yes/no response (Catherine \& Schonert-Reichl, 2011), children 
responded on a 4-point Likert scale using illustrations of thumbs in different positions ranging from $0=$ really not like me (thumbs down) to $3=$ really like me (thumbs up). Higher scores indicated higher levels of empathy (Cronbach's $\alpha=.82$ ).

Outgroup attitudes. Outgroup attitudes were assessed using a trait attribution task previously used with school children in Northern Ireland (Turner et al., 2013). Children were shown four positive (nice, friendly, good, kind) and four negative (horrible, unfriendly, bad, mean) traits, and reported how many people from the other community had each trait using a 4-point Likert scale from $0=$ none to $3=$ all, represented using different numbers of stick figures. Traits were presented in a random order and children completed one after the other. Negative traits were reverse scored and responses were then summed; higher scores reflected more positive outgroup attitudes (Cronbach's $\alpha=.86$ ).

Outgroup prosocial behavior. Children's prosocial behavior was measured using a behavioral task (Fehr, Bernhard, \& Rockenbach, 2008) which has been used in other settings of intergroup conflict (Bauer, Cassar, Chytilová, \& Henrich, 2014). The task consisted of three trials in which children allocated different numbers of sweets (gummy worms) between themselves and the outgroup; a sticker was used when parental consent forms indicted that the child did not like that type of sweet $(n=1)$ or could not eat the sweets for dietary reasons $(n=6)$. The sweets were placed directly in front of the children on laminated sheets.

Children were shown a laminated image of another primary school; the outgroup condition was operationalized by describing the image as either a 'Protestant' or a 'Catholic' school (i.e., child participants in a Catholic maintained school were told the image was a Protestant school). Children were also given a paper bag to collect their own sweets and wrote their name on it; the experimenter labeled a second bag with the outgroup school (i.e., Protestant or Catholic). 
In Trial 1 , children could choose to allocate either $[1,0]$ or $[1,1]$; that is, one sweet for themselves and no sweet to the outgroup, or one sweet to both themselves and the outgroup. In Trial 2, children could choose either $[2,0]$ or $[1,1]$, and in Trial 3, either $[1,2]$ or $[1,1]$. Trials were counter-balanced across children as was the side of the prosocial allocation.

For each trial, the number of sweets shared with the outgroup was coded as the prosocial response. For example, in Trial 1 scores could be 0 or 1, Trial 2: 0 or 1, and Trial 3: 2 or 1 , for a total of 1 to 4 with higher scores reflecting more outgroup prosocial behavior. As a frequency or count variable of the total number of sweets given, no internal consistency was conducted.

\section{Results}

The means, standard deviations, and bivariate correlations for variables in Study 1 are shown in Table 1. Mediation analysis was conducted using Model 4 in the PROCESS (Hayes, 2013) tool for SPSS using bootstrap mediation with 5,000 replications to examine the effect of dispositional empathy on outgroup prosocial behavior through children's outgroup attitudes (Figure 1); unstandardized regression coefficients were reported. Child age, gender, and community background were included in the model as demographic controls.

The overall model accounted for $31 \%$ of the variance in outgroup prosocial behavior. Regarding the demographic controls, females $(b=2.31$, se $=1.10, p<.05)$ and Catholics $(b=$ 2.28, $\mathrm{se}=1.14, p<.05)$ reported more positive attitudes than males and Protestants, respectively. No significant effect of age $(b=.07, \mathrm{se}=.07, p=.32)$, gender $(b=.30$, se $=$ $.19, p=.12)$, or community background $(b=-.29, \mathrm{se}=.20, p=.15)$ was found for outgroup prosocial behavior.

Within the proposed mediation, higher levels of empathy were related significantly to more positive outgroup attitudes $(b=.37, \mathrm{se}=.18, p<.05)$. More positive outgroup attitudes, in turn, were related to greater outgroup prosocial behavior $(\mathrm{b}=.09$, $\mathrm{se}=.02, p<.001)$. As 
zero was not included in the bootstrapped confidence interval, the indirect effect of empathy to children's outgroup prosocial behavior was significant $(b=.03$, se $=.02 ; 95 \% \mathrm{CI}: .001$, .083). In addition, the direct effect of empathy on outgroup prosocial behavior was not significant $(\mathrm{b}=-.01, \mathrm{se}=.03, p=.76)$, suggesting that the effect of dispositional empathy on outgroup prosocial behavior was fully mediated by outgroup attitudes. An exploratory analysis revealed that child age did not moderate any of the mediational paths (Model 59; Hayes, 2013). That is, the strength of the links from empathy to attitudes or action, or from attitudes to action, did not vary by child age in this sample.

\section{Discussion}

Study 1 explored the effect of dispositional empathy on the outgroup attitudes and prosocial behaviors during middle childhood for those growing up in post-accord Northern Ireland. The findings demonstrated that children's outgroup attitudes were a significant mediator between empathy and outgroup prosocial behaviors. That is, children with greater empathic ability also held more positive perceptions of other community, which in turn related to more prosocial behaviors across group lines. This finding is in line with the EAA model and suggests that dispositional empathy can promote constructive forms of engagement via outgroup attitudes in Northern Ireland. Consistent with previous research, children with higher levels of empathy may be better able to consider the feelings and needs of others (Eisenberg, 1990), including members of the traditional rival group (Halpern \& Weinstein, 2004). In turn, more positive outgroup attitudes may motivate intergroup helping (Batson \& Ahmad, 2009; Batson et al., 2002). These findings, however, should be considered in light of the study's limitations.

First, because of the cross-sectional, correlational design, it is not possible to make inferences about causation or the direction of effects (Maxwell \& Cole, 2007). That is, the EAA model proposes that empathy promotes more positive outgroup attitudes; however, the 
alternative direction or a reciprocal process could also hold. Therefore, longitudinal data is needed to unravel the direction of these effects. Second, the measure of outgroup prosocial behavior was fairly simple, as relevant for this age group; future research could adapt other forms of assessment and/or self-report measures (O’Driscoll et al., 2018; Taylor et al., 2014). Third, parental opt-in consent was at the lower end (Totura, Kutash, Labouliere, \& Karver, 2017), which is common in economically marginalized areas; although there were no indicators of systematic bias in these participation rates, future research may explore more active ways to recruit families. Fourth, past research has found that in adolescence, youth have an even greater opportunity to have a positive impact on society (Yates \& Youniss, 2006). However, within the context of Northern Ireland, intergroup tension can erode general prosocial acts as children transition through adolescence (Taylor et al., 2018). It is therefore particularly important to find ways to promote outgroup prosocial behaviors among this age group.

\section{Study 2}

Study 2 explored whether dispositional empathy can influence later outgroup attitudes and prosocial behaviors amongst adolescents in post-accord Northern Ireland using a longitudinal design for more robust inferences about the direction of effects (Maxwell \& Cole, 2007).

Adolescence often is viewed as a critical time when young people explore and consolidate their identities (Erikson, 1968). During adolescence, youth develop more advanced socio-cognitive and emotional skills, which may encourage greater prosocial responses (Eisenberg, 1990; Eisenberg, Miller, Shell, McNalley, \& Shea, 1991). However, longitudinal tests have found that general prosocial behaviors, i.e., those directed at any target, including family or ingroup members, decrease across adolescence in Northern Ireland (Taylor et al., 2018). As children move into adolescence, they become more aware of their 
social environment, and hostile intergroup relations may dampen helping behaviors across group lines. For example, children confronted with intergroup violence may respond with helping behaviors at first, but then recognize that these prosocial acts are rather futile (BarTal et al., 2017). Sustained exposure to a conflict-ridden environment may alter children's reasoning in relation to reconciliation and retaliation (Ardila-Rey, Killen, \& Brenick, 2009), particularly toward the traditional rival.

At the same time, adolescents tend to spend more time outside the home and, as such, may have more direct encounters with members of the other community (Leonard, 2010). Therefore, there is a need to uncover factors (e.g., empathy) that may encourage prosocial behaviors directed specifically at outgroup members. Such acts may also have a lasting impact, as prosocial behaviors during this developmental period can set a precedent for altruism across the lifespan (Bowman, Brandenberger, Lapsley, Hill, \& Quaranto, 2010). Study 2 , therefore, aimed to make a contribution to knowledge by examining the EAA model longitudinally amongst adolescents in post-accord Northern Ireland.

\section{Method}

\section{Participants}

Adolescents were recruited from eight post-primary schools across Northern Ireland (four state controlled de facto Protestant schools and four Catholic-maintained schools). Adolescents took part in two time points of data collection (spring and fall 2016). Five hundred adolescents participated at Time 1, however, thirty-four were removed from further analyses as they did not identify as members of either the Protestant or Catholic communities. Racial and ethnic backgrounds were not included as $98 \%$ of the population in Northern Ireland identified as White (Russell, 2013). The final sample at Time 1 therefore consisted of 466 adolescents, between 14 - to 15 -years-old, and evenly split by gender ( $50 \%$ female, $n=$ $232 ; 50 \%$ male, $n=234$ ) and community background (49\% Protestant, $n=230 ; 51 \%$ 
Catholic, $n=236)$. At Time 2 , the sample comprised of 383 returning adolescents $(82 \%$ retention), then between 15 - to 16 -years-old, and roughly split by gender ( $48 \%$ female, $n=$ $183 ; 52 \%$ male, $n=200$ ) and community background (53\% Protestant, $n=203 ; 47 \%$ Catholic, $n=180$ ). Given the design, Study 2 has statistical power to detect a small effect size (Cohen, 1992). Attrition analyses found that in comparison to those who remained in the study, adolescents who did not participate at Time 2 showed no significant differences in their Time 1 reports of dispositional empathy, outgroup attitudes, or outgroup prosocial behavior.

Where possible, adolescents were recruited from comprehensive schools. This was to ensure that different levels of academic ability were captured within the sample. All schools were segregated, with over $70 \%$ of students being either Protestant or Catholic (Northern Ireland Department of Education, 2016). As in Study 1, the sample included interface and non-interface schools with relatively similar levels of students eligible for FSM. In Study 2, the number of students eligible to receive FSM ranged from 30 to $65 \%$ (for more detail, see McKeown \& Taylor, 2018).

\section{Procedure}

At Time 1, principals provided written consent for data to be collected from students in year 11 (ages 14 to 15), and parental consent was obtained using an opt-out procedure because of participants' age. In each school, data collection was arranged to take place on a single day. Only students in classes that were scheduled to take place in the computer lab that day were recruited to take part; this scheduling led to an average $50 \%$ participation rate (49\% in Protestant and 52\% in Catholic schools). Due to the relative random nature of the day of data collection aligning with computer classes, there were no indications of systematic bias in the sample compared to school-wide data. Adolescents gave informed consent before participating; none opted out at this stage. 
At each time point, teachers brought their class to a computer room to complete an online self-report questionnaire using Qualtrics. These sessions lasted around 20 to 35 minutes and were supervised by trained experimenters. The experimenters provided information about the study and were then available to answer questions as the participants completed the questionnaire. Adolescents who participated at both time points were given a $£ 10(\sim \$ 13)$ Amazon gift voucher. Each school also received $£ 100(\sim \$ 135)$ for taking part in the study.

\section{Measures}

Dispositional empathy. Dispositional empathy was assessed using the empathic concern subscale of the IRI (Davis, 1994). The scale consisted of 4-items including, 'when I see someone being taken advantage of, I feel kind of protective toward them' and 'when I see someone being treated unfairly, I sometimes don't feel very much pity for them (reversescored).' Adolescents responded to each item using a 7-point Likert scale that ranged from 0 $=$ strongly disagree to $6=$ strongly agree. Higher scores reflected higher levels of empathy (Cronbach's $\alpha$ at Time $1=.61$; no improvement if any of the items were deleted).

Outgroup attitudes. Outgroup attitudes were measured using a single item adapted from Cairns, Kenworthy, Campbell, and Hewstone (2006). This measure had been used successfully to assess the intergroup attitudes of adolescents, including in Northern Ireland (Merrilees et al., 2017). At each time point, adolescents reported their overall feelings toward the other community on a 'feeling thermometer' from $0=$ unfavorable to $100=$ favorable. Higher scores indicated more positive outgroup attitudes.

Outgroup prosocial behavior. At each time point, outgroup prosocial behavior was measured using a single item previously used with youth in Northern Ireland (McKeown \& Taylor, 2018; Taylor et al., 2014). First, adolescents were presented with seven statements that outlined a range of prosocial behaviors - including helping, comforting, and sharing 
(Eisenberg et al., 2010). Then, the target of these acts was assessed using the single item:

'Thinking about all these things, how often do you do these toward people from the <outgroup> community?' using a 7-point Likert scale from $0=$ never to $6=$ very often. This single outgroup summary item was used in analyses with higher scores reflecting more outgroup prosocial behavior.

\section{Results}

The means, standard deviations, and bivariate correlations for all study variables are shown in Table 2. As in the previous study, mediation analysis was tested using the PROCESS Model 4 for SPSS to examine whether outgroup attitudes at Time 2 acted as a mediator between adolescents' dispositional empathy at Time 1 and their outgroup prosocial behaviors at Time 2 (Figure 2), controlling for Time 2 variables at Time 1. Indirect effects were estimated using bootstrapping with 5,000 replications and unstandardized regression coefficients were reported. The overall model accounted for $40 \%$ of the variance in outgroup prosocial behaviors at Time 2 .

Following Study 1, community background and gender were included as demographic controls; neither was a significant predictor of outgroup prosocial behaviors (background: $b=$ $5.15, \mathrm{se}=2.91, p=.08$; gender: $\mathrm{b}=.52, \mathrm{se}=3.03, p=.87)$. Age was not included as participants were the in the same year at each time point. Within the mediation, higher levels of empathy at Time 1 significantly predicted more positive outgroup attitudes at Time $2(\mathrm{~b}=$ $3.65, \mathrm{se}=1.47, p<.05)$, while controlling for Time 1 outgroup attitudes $(\mathrm{b}=.42$, se $=.05, p$ $<.001)$. More positive outgroup attitudes at Time 2, in turn, predicted greater outgroup prosocial behaviors at Time $2(\mathrm{~b}=.02, \mathrm{se}=.01, p<.001)$, even after controlling for adolescents' Time 1 reports of outgroup attitudes $(b=.01, \mathrm{se}=.01, p<.01)$ and outgroup prosocial behaviors $(\mathrm{b}=.24, \mathrm{se}=.04, p<.001)$. The indirect effect of Time 1 empathy to Time 2 outgroup prosocial behaviors was significant $(b=.09$, se $=.04 ; 95 \% \mathrm{CI}: .017, .175)$. 
The direct effect of Time 1 empathy was no longer a significant predictor of later prosocial behaviors toward the outgroup $(\mathrm{b}=.04, \mathrm{se}=.09, p=.70)$, indicating full mediation.

Two alternative models were tested; first, when also controlling for concurrent empathy (i.e., Time 2), the indirect effect was no longer significant. However, the mediation held within wave. That is, at Time 2 , the link from empathy to outgroup prosocial behavior was mediated by outgroup attitudes, with the same Time 1 controls. These findings suggest that there was significant stability across time and within-wave effects remained important for understanding the overall relations among constructs.

\section{Discussion}

Replicating Study 1, this study found that dispositional empathy is effective in fostering positive outgroup attitudes and prosocial behaviors amongst post-accord adolescents in Northern Ireland. Extending Study 1, Study 2 employed a longitudinal design, which allowed for the control of earlier levels of the mediator and outcome, enhancing knowledge about directionality. Across two time points, adolescents with higher levels of empathy later displayed more favorable attitudes and more self-reported outgroup helping. Moreover, outgroup attitudes mediated the impact of empathy on outgroup prosocial acts.

However, Study 2 also had limitations. To account for the direction of effects more accurately, it would have been ideal to use three time-points of data to test mediation (Maxwell \& Cole, 2007). Although this model tested the effects of earlier empathy on later attitudes and action, when the strength of within-wave correlation with empathy was taken into account, the cross-lagged mediation effect did not hold. This finding may highlight the lagged effects may be overshadowed by the impact of concurrent empathy. Taken into consideration with the low internal consistency of the empathy measure, future research should replicate these findings using different scales which tease apart state and trait empathy. 


\section{General Discussion}

The current paper contributes to a mounting body of research that aims to identify factors that promote positive intergroup attitudes and behaviors among young people growing up and living in divided societies (Aboud et al., 2012; Taylor et al., 2019). In particular, the paper advances understanding by testing the Empathy-Attitudes-Action (EAA) model during middle childhood and adolescence - two critical periods of development - in a post-accord society. In both cross-sectional (Study 1) and longitudinal (Study 2) designs, higher empathy related to more positive outgroup attitudes, which were linked to more outgroup prosocial behaviors, both self-report and concrete actions. These findings suggest that empathy may encourage youth to be sensitive to the feelings and needs of the other community. That is, empathy may enable children to value the welfare of outgroup members, which is exhibited as positive outgroup attitudes. These positive attitudes then motivate children and youth to engage in constructive outgroup action (Batson \& Ahmad, 2009; Batson et al., 2002).

The findings have practical implications. For example, prosocial behaviors often are used as an indicator of resilience in conflict settings (Haroz, Murray, Bolton, Betancourt, \& Bass, 2013). In addition, the current paper moves beyond the focus on general prosocial behaviors (Taylor et al., 2018), and most relevant to peacebuilding, focuses on those directed at outgroup members. That is, prosocial acts toward the traditional rival may provide a useful starting point for intergroup cooperation and establishing more peaceful relations (McKeown \& Taylor, 2018; Taylor et al., 2014). Empathy, therefore, may help to overcome group boundaries by promoting the antecedents of peacebuilding (Taylor \& McKeown, 2017).

The current paper has a number of strengths. For example, prosocial behavior was assessed by self-reporting of past behavior as well as actual behavior on game-like tasks toward the traditional rival outgroup, increasing ecological validity. In Study 2, an additional strength was the use of two time-points of data, which allowed for modeling directionality. 
Despite these strengths, there are a number of limitations across the two studies which could be addressed in future research.

First, in attempts to be child-friendly and easy to understand across a range of reading abilities in comprehensive schools, we used single-items or short scales, some with low internal consistency (e.g., empathy in Study 2). Although these demonstrated replicable effects and are consistent with previous developmental research (see Bigler, 1995), future work should consider more comprehensive measures that go beyond dispositional or trait empathy (see Padilla-Walker \& Carlo, 2014). Multidimensional measures of empathy, such as personal distress and perspective taking ability (Batson \& Ahmad, 2009), and related constructs such as sympathy (Eisenberg, 1990), may offer a more nuanced understanding. Empathy-induction, or other state-based forms of empathy, also may hold promise to promote intergroup prosocial intentions and behaviors among children (Sierksma et al., 2015; Taylor \& Glen, 2019). For example, concurrent experiences of empathy may be essential for understanding the decision to act prosocially or not across different intergroup settings. In addition, it would be useful to test if the EAA model is effective across other types of prosocial acts, for example civic engagement or peacebuilding (McKeown \& Taylor, 2017; Taylor et al., 2019). This approach may shed additional light on how to improve intergroup relations more broadly for those growing up in divided societies.

Second, schools in both interface and non-interface areas were recruited. Due to the economic marginalization of interface schools (i.e., there are no interface schools in affluent neighborhoods), non-interface schools with relatively similar levels of FSM were identified. Future research could replicate these studies in neighborhoods that are not economically marginalized, are more heterogenous, or in the $6 \%$ of integrated schools (Northern Ireland Department of Education, 2017). This approach would shed light on how these processes may generalize across Northern Ireland (O’Driscoll et al., 2018). 
Third, previous research in Northern Ireland indicates that families can contribute to the socialization of intergroup attitudes and behaviors throughout childhood and adolescence (Taylor et al., 2016, 2019), particularly around perception of the conflict (Taylor et al., 2019). Children's understanding of the past conflict or current tensions also may influence intergroup relations (Bar-Tal et al., 2017). Future studies should look at how the family can shape empathy development and the implications for outgroup prosocial behaviors.

Fourth, empathy and helping in contexts of intergroup conflict may also have a 'dark side.' For example, feeling empathetic toward outgroup members can lead to a perception that they are helpless or needy (Batson \& Ahmad, 2009). This may generate a power dynamic, which can impact the target's feelings of empowerment and self-esteem negatively (Schnabel \& Nadler, 2008). Similarly, participating in helping behaviors toward the other group may not always be considered a prosocial gesture; among majority group members, such acts could be used to reinforce perceptions of superiority and establish social dominance (Nadler, Harpaz-Gorodeisky, \& Ben-David, 2009). Future studies should examine the underlying motivations of children's and adolescent's empathy-related actions. Relatedly, the application of the developmental intergroup framework to test EAA could strengthen in the future by incorporating a social identity perspective (Bennett \& Sani, 2004; Nesdale et al., 2005) and considering the extent to which youth identify with their community background.

Despite these limitations, the current paper's findings have implications for practitioners operating in Northern Ireland and other post-accord regions. That is, empathy may promote the antecedents of peacebuilding and contribute to social reconstruction (Halpern \& Weinstein, 2004; McKeown \& Taylor, 2017). Over 20 years have passed since the Belfast/Good Friday Agreement; however, the peace process remains brittle, as both groups are reluctant to act to benefit the other. In order to break the transgenerational cycle of intergroup tension and division (Taylor, Štambuk, Čorkalo Biruški, \& O’Driscoll, 2019), 
there is a need to support those born after the height of the violence. Encouraging these children and adolescents to engage in constructive interactions, such as outgroup prosocial behaviors, may contribute to broader social and political change that can consolidate peace. These findings may have implications for other post-accord regions. 


\section{References}

Aboud, F.E. (1988). Children and prejudice. Oxford, UK: Basil Blackwell Inc.

Aboud, F.E., \& Levy, S.R. (2000). Interventions to reduce prejudice and discrimination in children and adolescents. In S. Oskamp (Ed.), Reducing prejudice and discrimination. The Claremont symposium on applied social psychology (pp. 269-293). Mahwah, NJ, US: Lawrence Erlbaum Associates.

Aboud, F.E., Tredoux, C., Tropp, L.R., Spears Brown, C., Niens, U., Noor, N.M., \& the UNA Global Evaluation Group (2012). Interventions to reduce prejudice and enhance inclusion and respect for ethnic differences in early childhood: A systematic review. Developmental Review, 32, 307-336. https://doi.org/10.1016/j.dr.2012.05.001.

Abrams, D., \& Killen, M. (2014). Social exclusion of children: Developmental origins of prejudice. Journal of Social Issues, 70, 1-11. https://doi.org/10.1111/josi.12043.

Abrams, D., Van de Vyver, J., Pelletier, J., \& Cameron, L. (2015). Children's prosocial behavioural intentions towards outgroup members. British Journal of Developmental Psychology, 33, 277-294. https://doi.org/10.1111/bjdp.12085.

Ajzen, I., \& Fishbein, M. (2005). The influence of attitudes on behavior. In D. Albarracín, B.T. Johnson, \& M.P. Zanna (Eds.), The handbook of attitudes (pp. 173-221), London: Lawrence Erlbaum Associates.

Ardila-Rey, A., Killen, M., \& Brenick, A. (2009). Moral reasoning in violent contexts: Displaced and non-displaced Colombian children's evaluations of moral transgressions, retaliation, and reconciliation. Social Development, 18, 181-209. https://doi.org/10.1111/j.1467-9507.2008.00483.x.

Bar-Tal, D., Diamond, A.H., \& Nasie, M. (2017). Political socialization of young children in intractable conflicts: Conception and evidence. International Journal of Behavioral Development, 41, 415-425. https://doi.org/10.1177/0165025416652508. 
Batson, C.D. (1991). The altruism question: Toward a social-psychological answer. Hillsdale, NJ: Lawrence Erlbaum.

Batson, C.D. (2010). Empathy-induced altruistic motivation. In M. Mikulincer, \& P.R. Shaver (Eds.), Prosocial motives, emotions, and behavior: The better angels of our nature (pp. 15-34). Washington, D.C.: American Psychological Association Press.

Batson, C.D., \& Ahmad, N.Y. (2009). Using empathy to improve intergroup attitudes and relations. Social Issues and Policy Review, 3, 141-177.

http://dx.doi.org/10.1111/j.1751-2409.2009.01013.x.

Batson, C.D., Chang, J., Orr, R., \& Rowland, J. (2002). Empathy, attitudes, and action: Can feeling for a member of a stigmatized group motivate one to help the group? Personality and Social Psychology Bulletin, 28, 1656-1666. https://doi.org/10.1177/014616702237647.

Batson, C.D., \& Moran, T. (1999). Empathy-induced altruism in a prisoner's dilemma. European Journal of Social Psychology, 29, 909-924. https://doi.org/10.1002/(SICI)1099-0992(199911)29:7<909::AID-

\section{EJSP965>3.0.CO;2-L.}

Batson, C.D., Polycarpou, M.P., Harmon-Jones, E., Imhoff, H.J., Mitchener, E.C., Bednar, L.L., ... Highberger, L. (1997). Empathy and attitudes: Can feeling for a member of a stigmatized group improve feelings toward the group? Journal of Personality and Social Psychology, 72, 105-118. http://dx.doi.org/10.1037/0022-3514.72.1.105.

Bauer, M., Cassar, A., Chytilová, J., \& Henrich, J. (2014). War's enduring effects on the development of egalitarian motivations and in-group biases. Psychological Science, 25, 47-57. https://doi.org/10.1177/0956797613493444.

Beelmann, A., \& Heinemann, K.S. (2014). Preventing prejudice and improving intergroup attitudes: A meta-analysis of child and adolescent training programs. Journal of 
Applied Developmental Psychology, 35, 10-24.

http://dx.doi.org/10.1016/j.appdev.2013.11.002.

Bennett, M., \& Sani, F. (2004). The development of the social self. New York: Psychology Press.

Bigler, R.S. (1995). The role of classification skill in moderating environmental influences on children's gender stereotyping: A study of the functional use of gender in the classroom. Child Development, 66, 1072-1087. https://doi.org/10.1111/j.14678624.1995.tb00923.x.

Bowman, N., Brandenberger, J., Lapsley, D., Hill, P., \& Quaranto, J. (2010). Serving in college, flourishing in adulthood: Does community engagement during the college years predict adult well-being? Applied Psychology: Health and Well-Being, 2, 14-43. https://doi.org/10.1111/j.1758-0854.2009.01020.x.

Cairns, E., Kenworthy, J., Campbell, A., \& Hewstone, M. (2006). The role of ingroup identification, religious group membership, and intergroup conflict in moderating ingroup and out-group affect. British Journal of Social Psychology, 45, 701-716. https://doi.org/10.1348/014466605X69850.

Catherine, N.L., \& Schonert-Reichl, K.A. (2011). Children's perceptions and comforting strategies to infant crying: Relations to age, sex, and empathy-related responding. British Journal of Developmental Psychology, 29, 524-551. https://doi.org/10.1348/026151010X521475.

Cohen, J. (1992). A power primer. Psychological Bulletin, 112, 155-159. http://dx.doi.org/10.1037/0033-2909.112.1.155.

Cummings, E.M., Goeke-Morey, M., Merrilees, C.E., Taylor, L.K., \& Shirlow, P. (2014). A social-ecological, process-oriented perspective on political violence and child 
development. Child Development Perspectives, 8, 82-89.

https://doi.org/10.1111/cdep.12067.

Davis, M.H. (1983). Measuring individual differences in empathy: Evidence for a multidimensional approach. Journal of Personality and Social Psychology, 44, 113 126. http://dx.doi.org/10.1037/0022-3514.44.1.113.

Davis, M.H. (1994). Empathy: A social psychological approach. Madison, WI: Brown and Benchmark.

Dovidio, J.F., Piliavin, J.A., Schroeder, D.A., \& Penner, L.A. (2017). The social psychology of prosocial behavior. Mahwah, NJ: Erlbaum. https://doi.org/10.4324/9781315085241.

Eisenberg, N. (1990). Prosocial development in early and mid-adolescence. In R, Montemayor, G.R. Adams, \& T.P. Gullotta (Eds.), Advances in adolescent development: An annual book series, Vol. 2. From childhood to adolescence: A transitional period? (pp. 240-268). Thousand Oaks, CA, US: Sage Publications, Inc.

Eisenberg, N., Eggum, N.D., \& Di Giunta, L. (2010). Empathy-related responding: Associations with prosocial behavior, aggression, and intergroup relations. Social Issues and Policy Review, 4, 143-180. https://doi.org/10.1111/j.17512409.2010.01020.x.

Eisenberg, N., \& Miller, P.A. (1987). The relation of empathy to prosocial and related behaviors. Psychological Bulletin, 101, 91-119. http://dx.doi.org/10.1037/00332909.101.1.91.

Eisenberg, N., Miller, P.A., Shell, R., McNalley, S., \& Shea, C. (1991). Prosocial development in adolescence: A longitudinal study. Developmental Psychology, 27, 849-857. http://dx.doi.org/10.1037/0012-1649.27.5.849.

Erikson, E.H. (1968). Identity: Youth and crisis. Oxford, England: Norton \& Co. 
Fehr, E., Bernhard, H., \& Rockenbach, B. (2008). Egalitarianism in young children. Nature, 454, 1079-1081. https://doi.org/10.5167/uzh-3833.

Findlay, L.C., Girardi, A., \& Coplan, R.J. (2006). Links between empathy, social behavior, and social understanding in early childhood. Early Childhood Research Quarterly, 21, 347-359. https://doi.org/10.1016/j.ecresq.2006.07.009.

Halpern, J., \& Weinstein, H.M. (2004). Rehumanizing the other: Empathy and reconciliation. Human Rights Quarterly, 26, 561-583. https://doi.org/10.1353/hrq.2004.0036

Haroz, E.E., Murray, L.K., Bolton, P., Betancourt, T.S., \& Bass, J.K. (2013). Adolescent resilience in Northern Uganda: The role of social support and prosocial behavior in reducing mental health problems. Journal of Research on Adolescence, 23, 138-148. https://doi.org/10.1111/j.1532-7795.2012.00802.x.

Hayes, A.F. (2013). Introduction to mediation, moderation and conditional process analysis: A regression-based approach. New York, NY: The Guilford Press.

Kelman, H.C. (2008). Evaluating the contributions of interactive problem solving to the resolution of ethnonational conflicts. Peace and Conflict: Journal of Peace Psychology, 14, 29-60. https://doi.org/10.1080/10781910701839767.

Leonard, M. (2010). What's recreational about 'recreational rioting'? Children on the streets in Belfast. Children \& Society, 24, 38-49. https://doi.org/10.1111/j.1099$\underline{0860.2008 .00190 . x}$.

Malhotra, D., \& Liyanage, S. (2005). Long-term effects of peace workshops in protracted conflicts. Journal of Conflict Resolution, 49, 908-924. https://doi.org/10.1177/0022002705281153.

Malti, T., Gummerum, M., Keller, M., \& Buchmann, M. (2009). Children's moral motivation, sympathy, and prosocial behavior. Child Development, 80, 442-460. https://doi.org/10.1111/j.1467-8624.2009.01271.x. 
Maxwell, S.E., \& Cole, D.A. (2007). Bias in cross-sectional analyses of longitudinal mediation. Psychological Methods, 12, 23-44. https://doi.org/10.1037/1082989X.12.1.23.

McEvoy-Levy, S. (2006). Troublemakers or peacemakers? Youth and post-accord peacebuilding. Notre Dame, IN: Notre Dame Press.

McKeown, S. \& Taylor, L.K. (2017). Intergroup contact and peacebuilding: Promoting youth civic engagement in Northern Ireland. Journal of Social and Political Psychology, 5, 415-434. https://doi.org/10.5964/jspp.v5i2.769.

McKeown, S. \& Taylor, L.K. (2018). Perceived peer and school norm effects on youth antisocial and prosocial behaviours through intergroup contact in Northern Ireland. British Journal of Social Psychology, 57, 652-665. https://doi.org/10.1111/bjso.12257.

Merrilees, C.E., Cairns, E., Taylor, L.K., Goeke-Morey, M.C., Shirlow, P., \& Cummings, E.M. (2013). Social identity and youth aggressive and delinquent behaviors in a context of political violence. Political Psychology, 34, 695-711. https://doi.org/10.1111/pops.12030.

Merrilees, C.E., Taylor, L.K., Baird, R., Goeke-Morey, M.C., Shirlow, P., \& Cummings, E.M. (2017). Neighborhood effects of intergroup contact on change in youth intergroup bias. Journal of Youth and Adolescence, 47, 77-87. https://doi.org/10.1007/s10964-017-0684-6.

Miller, P.A., Eisenberg, N., Fabes, R.A., \& Shell, R. (1996). Relations of moral reasoning and vicarious emotion to young children's prosocial behavior toward peers and adults. Developmental Psychology, 31, 210-219. http://dx.doi.org/10.1037/0012$\underline{1649.32 .2 .210 .}$ 
Muldoon, O.T. (2013). Understanding the impact of political violence in childhood: A theoretical review using a social identity approach. Clinical Psychology Review, 33, 929-939. https://doi.org/10.1016/j.cpr.2013.07.004.

Nadler, A., Harpaz-Gorodeisky, G., \& Ben-David, Y. (2009). Defensive helping: Threat to group identity, ingroup identification, status stability, and common group identity as determinants of intergroup help-giving. Journal of Personality and Social Psychology, 97, 823-834. http://dx.doi.org/10.1037/a0015968.

Nesdale, D., Griffiths, J., Durkin, K., \& Maass, A. (2005). Empathy, group norms and children’s ethnic attitudes. Journal of Applied Developmental Psychology, 26, 623 637. http://dx.doi.org/10.1016/j.appdev.2005.08.003.

Northern Ireland Department of Education. (2016). School enrolments - school level data 2016/17. https://www.education-ni.gov.uk/publications/school-enrolments-schoollevel-data-201617.

Northern Ireland Department of Education. (2017). Integrated schools. https://www.education-ni.gov.uk/articles/integrated-schools.

O’Driscoll, D., Taylor, L.K., \& Dautel, J. (2018). Intergroup resource distribution among children living in segregated neighborhoods amid protracted conflict. Peace and Conflict: Journal of Peace Psychology, 24, 464-474. http://dx.doi.org/10.1037/pac0000348.

Padilla-Walker, L.M., \& Carlo, G. (2014). Prosocial development: A multidimensional approach. New York, NY: Oxford University Press. https://doi.org/10.1093/acprof:oso/9780199964772.001.0001.

Russell, R. (2013). Census 2011: Detailed characteristics of ethnicity and country of birth at the Northern Ireland level. Northern Ireland Assembly: Northern Ireland Assembly. Belfast. 
Rutland, A., Abrams, D., \& Levy, S. (2007). Extending the conversation: Transdisciplinary approaches to social identity and intergroup attitudes in children and adolescents. International Journal of Behavioral Development, 31, 417-418. https://doi.org/10.1177/0165025407083669.

Rutland, A., Killen, M., \& Abrams, D. (2010). A new social-cognitive developmental perspective on prejudice: The interplay between morality and group identity. Perspectives on Psychological Science, 5(3), 279-291. https://doi.org/10.1177/1745691610369468

Schnabel, N., \& Nadler, A. (2008). A needs-based model of reconciliation: Satisfying the different needs of victim and perpetrator. Journal of Personality and Social Psychology, 94, 116-132. https://doi.org/10.1037/0022-3514.94.1.116.

Sierksma, J., Thijs, J., \& Verkuyten, M. (2014). Children's intergroup helping: The role of empathy and peer group norms. Journal of Experimental Child Psychology, 126, 369383. https://doi.org/10.1016/j.jecp.2014.06.002.

Sierksma, J., Thijs, J., \& Verkuyten, M. (2015). In-group bias in children's intention to help can be overpowered by inducing empathy. British Journal of Developmental Psychology, 33, 45-56. https://doi.org/10.1111/bjdp.12065.

Stephan, C.W., \& Finlay, K. (1999). The role of empathy in improving intergroup relations. Journal of Social Issues, 55, 729-743. https://doi.org/10.1111/0022-4537.00144.

Taylor, L.K., \& Glen, C. (2019). From empathy to action: Can enhancing host-society children's empathy promote positive attitudes and prosocial behavior towards refugees? Journal of Community and Applied Social Psychology. https://doi.org/10.1002/casp.2438 
Taylor, L.K., \& Hanna, J.R. (2018). Altruism born of suffering among emerging adults in Northern Ireland. Journal of Aggression, Conflict and Peace Research, 10, 157-169. https://doi.org/10.1108/JACPR-01-2017-0271.

Taylor, L.K., \& McKeown, S. (2017). Youths’ peacebuilding potential: Intergroup contact and civic participation amongst a post-accord generation in Northern Ireland. In K. Niven, S. Lewis, \& C. Kagan (Eds.), Making a difference with psychology (pp. 5662). London, UK: Richard Benjamin Trust.

Taylor, L.K., Merrilees, C.E., Baird R., Goeke-Morey, M.C., Shirlow, P., \& Cummings, E.M. (2018). Impact of political conflict on trajectories of adolescent prosocial behavior: Implications for civic engagement. Developmental Psychology, 54, 1785-1794. http://dx.doi.org/10.1037/dev0000552.

Taylor, L.K., Merrilees, C.E., Goeke-Morey, M.C., Shirlow, P., \& Cummings, E.M. (2014). Political violence and adolescent outgroup attitudes and prosocial behaviors: Implications for positive intergroup relations. Social Development, 23, 840-859. https://doi.org10.1111/sode.12074.

Taylor, L.K., Merrilees, C.E., Goeke-Morey, M.C., Shirlow, P., \& Cummings, E.M. (2016). Trajectories of adolescent aggression and family cohesion: The potential to perpetuate or ameliorate political conflict. Journal of Clinical Child and Adolescent Psychology, 45, 114-28. https://doi.org/10.1080/15374416.2014.945213.

Taylor, L.K., Štambuk, M., Čorkalo Biruški, D., \& O’Driscoll, D. (2019). Transgenerational transmission of collective victimhood through a developmental intergroup framework: The lasting power of group narratives of suffering. In J. Vollhardt (Ed.), The Social Psychology of Collective Victimhood. United Kingdom: Oxford University Press. 
Taylor, L.K., Townsend, D., Merrilees, C.E., Goeke-Morey, M.C., Shirlow, P., \& Cummings, E.M. (2019). Adolescent civic engagement and perceived political conflict: The role of family cohesion. Youth \& Society, 51, 616-637. https://doi.org/10.1177/0044118X17697236.

Totura, C.M., Kutash, K., Labouliere, C.D, \& Karver, M.S. (2017). Evaluating active parental consent procedures for school programming addressing the sensitive topic of suicide prevention. Journal of School Health, 87(2), 114-120. https://doi.org/10.1111/josh.12473

Turner, R.N., Tam, T., Hewstone, M., Kenworthy, J., \& Cairns, E. (2013). Contact between Catholic and Protestant schoolchildren in Northern Ireland. Journal of Applied Social Psychology, 43, 216-228. https://doi.org/10.1111/jasp.12018.

Vezzali, L., Cadamuro, A., Versari, A., Giovannini, D., \& Trifiletti, E. (2015). Feeling like a group after a natural disaster: Common ingroup identity and relations with outgroup victims among majority and minority young children. British Journal of Social Psychology, 54, 519-538. https://doi.org/10.1111/bjso.12091.

Yates, M., \& Youniss, J.J. (Eds.) (2006). Roots of civic identity: International perspectives on community service and activism in youth. New York: Cambridge University Press. 
Table 1

Means, standard deviations, and bivariate correlations for all Study 1 variables $(N=132)$

\begin{tabular}{|c|c|c|c|c|c|c|c|}
\hline Variables & $M$ & $S D$ & 1 & 2 & 3 & 4 & 5 \\
\hline 1 Female & \multicolumn{2}{|c|}{$56.06 \%$ female, $43.94 \%$ male } & - & & & & \\
\hline 2 Catholic & \multicolumn{2}{|c|}{$31.06 \%$ Catholic, $68.94 \%$ Protestant } & .10 & - & & & \\
\hline 3 Age & 8.42 & 1.23 & -.01 & -.04 & - & & \\
\hline 4 Empathy & 15.22 & 3.40 & $.21^{*}$ & .06 & .10 & - & \\
\hline 5 Outgroup attitudes & 18.62 & 4.88 & $.26^{* *}$ & .13 & -.01 & $.25^{* *}$ & - \\
\hline 6 Outgroup prosocial behavior & 1.50 & .95 & $.26^{*}$ & .01 & .15 & .11 & $.50^{* * *}$ \\
\hline
\end{tabular}

Note: $* p<.05, * * p<.01, * * * p<.001$. 
Table 2

Means, standard deviations, and bivariate correlations for all Study 2 variables $(N=466)$

\begin{tabular}{|c|c|c|c|c|c|c|c|c|c|}
\hline Variables & $M$ & $S D$ & 1 & 2 & 3 & 4 & 5 & 6 & 7 \\
\hline 1 Female (T1) & \multicolumn{2}{|c|}{$\begin{array}{l}49.79 \% \text { female, } \\
50.21 \% \text { male }\end{array}$} & - & & & & & & \\
\hline 2 Catholic (T1) & \multicolumn{2}{|c|}{$\begin{array}{l}50.64 \% \text { Catholic, } \\
49.36 \% \text { Protestant }\end{array}$} & $.54^{* * *}$ & - & & & & & \\
\hline 3 Empathy (T1) & 4.98 & .92 & $.40^{* * *}$ & $.27^{* * *}$ & - & & & & \\
\hline 4 Empathy (T2) & 5.00 & .93 & $.41^{* * *}$ & $.27^{* * *}$ & $.52^{* * *}$ & - & & & \\
\hline 5 Outgroup attitudes (T1) & 50.48 & 27.58 & $.18^{* * *}$ & .01 & $.26^{* * *}$ & $.26^{* * *}$ & - & & \\
\hline 6 Outgroup attitudes (T2) & 62.46 & 27.05 & $.19^{* * *}$ & .08 & $.27^{* * *}$ & $.37^{* * *}$ & $.48^{* * *}$ & - & \\
\hline 6 Outgroup prosocial behavior (T1) & 2.22 & 1.91 & $.11^{*}$ & -.01 & $.18^{* * *}$ & $.21^{* * *}$ & $.45^{* * *}$ & $.28^{* * *}$ & - \\
\hline 8 Outgroup prosocial behavior (T2) & 2.43 & 1.87 & $.21^{* * *}$ & .05 & $.24^{* * *}$ & $.37^{* * *}$ & $.48^{* * *}$ & $.53^{* * *}$ & $.44^{* * *}$ \\
\hline
\end{tabular}

Note: $* p<.05, * * p<.01, * * * p<.001$ 
Figure 1. Bootstrapped mediation model for Study 1. Unstandardized regression coefficients are reported with standard errors included in parentheses. Demographic control variables of age, gender, and community background have been removed to improve the overall readability of the model. Note: $* p<.05,{ }^{* *} p<.01, * * * p<.001$.

$.03(.02), 95 \%$ CI: .001, .083

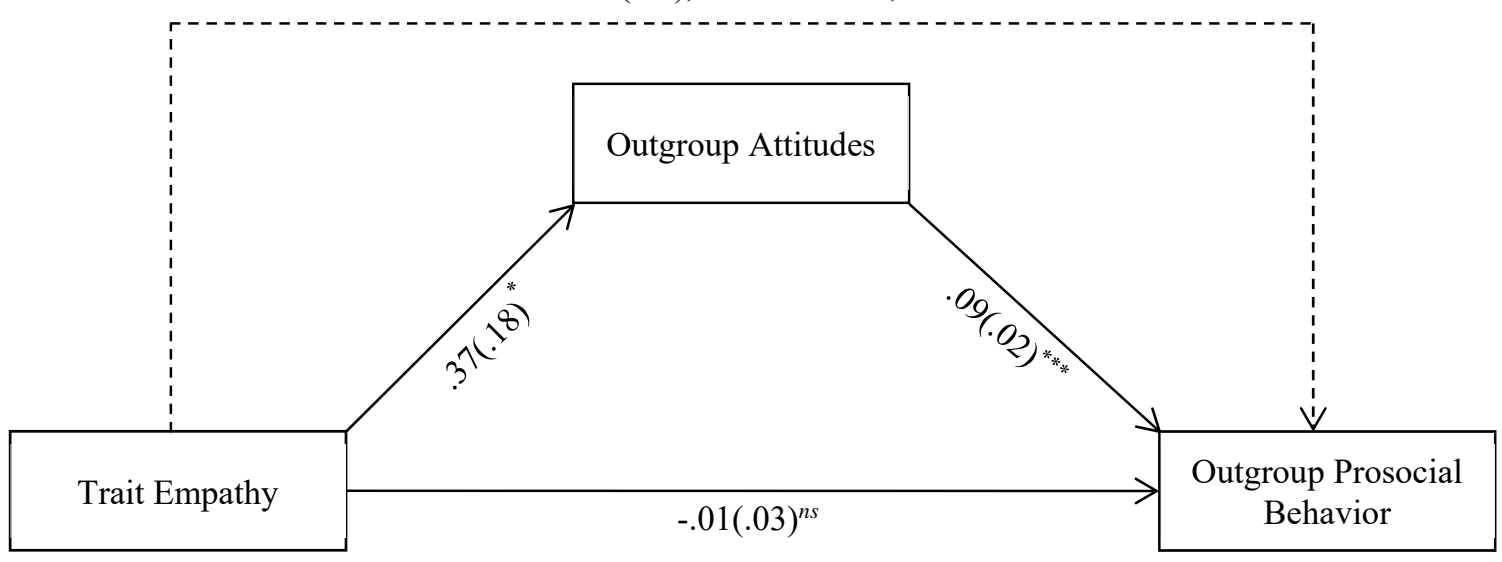


Figure 2. Bootstrapped mediation model for Study 2. Unstandardized regression coefficients are reported with standard errors included in parentheses. The control variables of gender, community background, outgroup attitudes (T1), and outgroup prosocial behavior (T1) have been removed to improve the overall readability of the model. Note: ${ }^{*} p<.05,{ }^{* *} p<.01$, $* * * p<.001$.

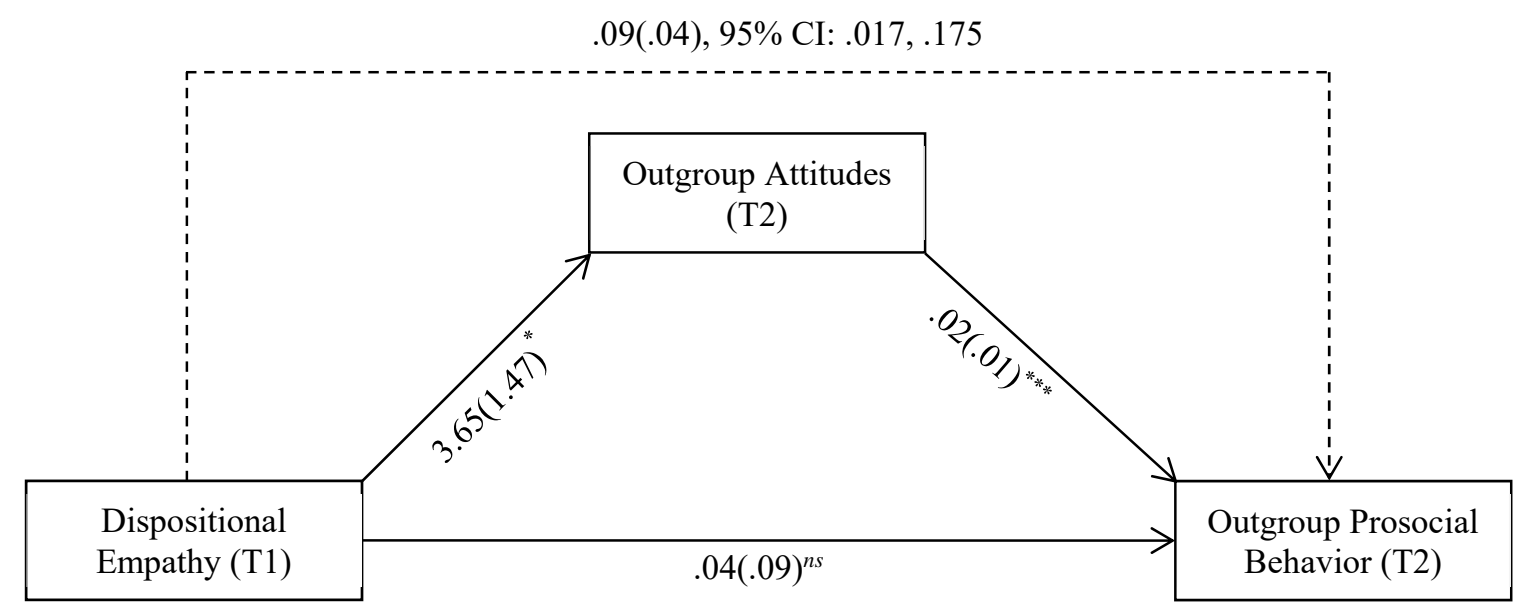

